\title{
haEMATOLOgICAL VALUES IN THE PERIPHERAL BLOOD OF ZEBRAS KEPT IN THE EAST-BOHEMIAN ZOOLOGICAL GARDEN AT DVŮR KRÁLOVÉ
}

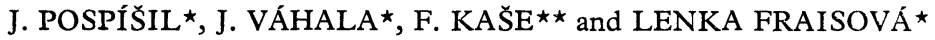

*East-Bohemian Zoological Garden, 54401 Dvůr Králové, Czechoslovakia

$\star \star$ Policlinic of the District Institute of National Health, 40001 Ústí nad Labem, Czechoslovakia

Received November 21, 1983

\begin{abstract}
Pospíšil J., J. Váhala, F. Kaše and Lenka Fraisová: Haematological Values in the Peripheral Blood of Zebras Kept in the East-Bohemian Zoological Garden at Dvưr Králové. Acta vet. Brno, 54, 1985: 129-140.

Comprehensive veterinary care of animals kept in the East-Bohemian Zoological Garden at Dvưr Králové includes systematic investigations of haematological values in the peripheral blood of the animals with respect to their clinical health status.

The present report gives the results of haematological examination of the peripheral blood in clinically healthy 30 female and 3 male Grévy's zebras (Equus Grevyi), 21 female and 3 male Böhm's zebras (Equus Burchelli Boehmi), 4 female dammar zebras (Equus Burchelli antiquorum), 9 female and 2 male Hartman's zebras (Equus Hartmanae). Erythrocyte count, haematocrit, haemoglobin content, leukocyte count, differential leukocyte count, thrombocyte count, coagulation time and thromboplastin time (Quick's test) were determined in the peripheral blood of the animals and the values obtained for females of each zebra species under study were averaged. Problems of the term "clinically healthy animal" in zoos considering their specific conditions as well as problems associated with blood collection in non-domesticated animals and effects on haematological values due to handling of the animals are discussed. The peripheral blood values reported in the study provide basic information about haematological parameters in the peripheral blood of clinically healthy zebras of the four species.
\end{abstract}

Basic data, hematology, zebra species, male, female.

In the East-Bohemian Zoological Garden at Dvůr Králové, conditions have been set up for laboratory-clinical examination of animals by establishment of laboratories which, among other things, have to substantiate clinical diagnosis in diseased or suspect animals by laboratory methods. The first step is to find what clinical and laboratory values can be expected in clinically healthy animals. Two sources of obtaining information to this effect are available:

1. Relevant Literature. Published data are of great help but the possibility should always be considered that the values reported in the literature were obtained in animals kept under entirely different climatic, husbandry, feeding and housing conditions. These factors come to the fore particularly in zoos where animals are kept, to a certain degree, under unnatural conditions compared with free-living animals whereby values under study can be markedly affected.

2. Exploratory Laboratory Examination. This way is tedious, incurring much time and effort, but offers certain advantages over the foregoing approach: examination is carried out on animals kept under given clinical and husbandry conditions by the same methods as will be used in examining diseased animals.

Both approaches have a shortcoming in that the values are often obtained in small groups of animals of different origin, age and physiological state (oestrus, pregnancy, lactation) during different seasons of the year and may be affected by these factors. We think it expedient to adopt the latter approach for obtaining basic clinical and laboratory values in apparently healthy animals in our zoo. 
Table 1a

Survey of haematological values in the peripheral blood of the Böhm's zebra (Equus Burchelli Boehmi) reported in the literature

\begin{tabular}{|c|c|c|c|}
\hline Author & JONES (1976) & HAW KEY (1975) & SEAL (1977) \\
\hline No. animals examined & 11 & 5 & 25 \\
\hline $\begin{array}{l}\text { Erythrocyte count }\left(10^{12} / 1\right) \\
\text { Haematocrit } 1 / 1 \\
\text { Haemoglobin content }(\mathrm{g} / 1) \\
\text { Mean corpuscular haemoglobin (fmol) } \\
\text { Mean corpuscular haemoglobin concentration } \\
\text { (mmol/1) } \\
\text { Mean corpuscular volume (fl) }\end{array}$ & $\begin{array}{cc}8.8 & (7.25-10.4) \\
0.406 & (0.36-0.44) \\
148.0 & (133-160) \\
10.5 & (8,68-12,10) \\
22.52 & (20,47-24.20) \\
46.9 & (36.1-57.7)\end{array}$ & $\begin{array}{c}8.3(7,4-9,7) \\
0.44(0.38-0.54) \\
145.0(132-176) \\
11.60(9,43-13.46) \\
21.53(19.54-24.20) \\
54.0(42.0-66.0)\end{array}$ & $\begin{aligned} 9,95 & \pm 1,1 \\
0.42 & \pm 0.03 \\
153.0 \pm 16 & \\
/ & \\
22.40 & \pm 1.36 \\
41.0 & \pm 3.9\end{aligned}$ \\
\hline $\begin{array}{l}\text { Leukocyte count }\left(10^{9} / 1\right) \\
\text { Lymphocytes } \\
\text { Monocytes } \\
\text { Neutrophils } \\
\text { Eosinophils } \\
\text { Basophils }\end{array}$ & $\begin{array}{l}11.7(4.4-25,8) \\
0.34(0.15-0.55) \\
0.02(0.00-0.03) \\
0.59(0.49-0.72) \\
0.01(0.00-0.04) \\
0.02\end{array}$ & $\begin{array}{ll}8.3 & (7.4-9.7) \\
0.28 & (0.14-0.52) \\
0.03 & (0.02-0.06) \\
0.67 & (0.43-0.83) \\
0.01 & (0.00-0.04) \\
0.005 & (0.00-0.04)\end{array}$ & $6,0 \pm 2.4$ \\
\hline Thrombocyte count $\left(10^{9} / 1\right)$ & $175.0(100-273)$ & $193.0(155-258)$ & 1 \\
\hline
\end{tabular}

$I=$ Values not given.

Table 1b

Survey of haematological values in the peripheral blood of the Grévy's zebra (Equus Grevyi) and the Hartman's zebra (Equus zebra Hartmanae) reported in the literature

\begin{tabular}{|c|c|c|c|}
\hline Species & $\begin{array}{l}\text { Grévy's zebra } \\
\text { (Equus Grevyi) }\end{array}$ & $\begin{array}{r}\text { Hartman's } z \\
\text { (Equus zebra }\end{array}$ & $\begin{array}{l}\text { bra } \\
\text { Hartmanae) }\end{array}$ \\
\hline Author & Hawkey (1975) & JONES (1976) & HAW KEY (1975) \\
\hline No. animals examined & 1 & 8 & $5(4)$ \\
\hline $\begin{array}{l}\text { Erythrocyte count }\left(10^{12} / \mathrm{l}\right) \\
\text { Haematocrit } 1 / 1 \\
\text { Haemoglobin content }(\mathrm{g} / \mathrm{l}) \\
\text { Mean corpuscular haemoglobin (fmol) } \\
\text { Mean corpuscular haemoglobin conc. } \\
\text { (mmol/1) } \\
\text { Mean corpuscular volume (fl) }\end{array}$ & $\begin{array}{l}9.4 \\
0.48 \\
174,0 \\
11.5 \\
\\
22.34 \\
51.0\end{array}$ & $\begin{array}{cl}8.9 & (7.0-10.0) \\
0.397 & (0.35-0.44) \\
139.0 & (124-156) \\
9.74 & (8.87-10.92) \\
& \\
21.78 & (21.03-22.46) \\
44.7 & (41.7-49.8)\end{array}$ & $\begin{array}{c}8.5(7.7-9.5) \\
0.39(0.36-0.46) \\
142.0(132-153) \\
10.24(9.93-10.73) \\
21.28(19.54-23.53) \\
46.1(38.6-54.0)\end{array}$ \\
\hline $\begin{array}{l}\text { Leukocyte count }\left(10^{9} / 1\right) \\
\text { Lymphocytes } \\
\text { Monocytes } \\
\text { Neutrophils } \\
\text { Eosinophils } \\
\text { Basophils }\end{array}$ & $\begin{array}{l}9,9 \\
0.14 \\
0.06 \\
0.83 \\
0.00 \\
0.00\end{array}$ & $\begin{array}{l}10.3(7.5-13.1) \\
0.54(0.43-0.63) \\
0.01(0.00-0.04) \\
0.41(0.35-0.49) \\
0.03(0.00-0.07) \\
0.00\end{array}$ & $\begin{array}{l}8.1(7.3-8.9) \\
0.32(0.21-0.40) \\
0.04(0.01-0.09) \\
0.63(0.54-0.76) \\
0.01(0.00-0.02) \\
0.00\end{array}$ \\
\hline Thrombocyte count $\left(10^{9} / 1\right)$ & 253.0 & $150.0(75.0-178.0)$ & $214.0(16 \dot{2} .0-360.0)$ \\
\hline
\end{tabular}


The object of the present report is presentation and evaluation of haematological values obtained in "clinically healthy" zebras kept in the Zoological Garden at Dvurr Králové.

The data on haematological values in the peripheral blood of clinically healthy zebras found by us in the literature are summarized in Tables la and 1b. They were reported by three investigators. Those given by Hawkey (1975) were obtained in one Grévy's zebra and 5 (4) Hartman's zebras, those of Jones (1976) were obtained in 8 Hartman's zebras and 11 Böhm's zebras. In the latter study blood collections were made from animals immobilized by administration of etorphine and acepromazine. The time elapsing between the administration of the immobiizirg agents (of laying-down of the animals) and blood collections was not specified. The blood collections were carried out in Whipsnade Park during a 6-year period. The data reported by Sealet al. (1977) were obtained in 25 Böhm's zebras immobilized by administration of etorphine and did not include the differential leukocyte count.

Not included in Table $1 \mathrm{a}$ are the data of Masui et al. (1975) who found $11.26\left(10^{12} / 1\right)$ erythrocytes and $21.4 / 10^{9} / 1$ ) leukocytes in a female Böhm's zebra having $250 \mathrm{~kg}$ in body mass and pretreated by administration of ketamine.

\section{Materials and Methods}

In all, 30 female and 3 male Grévy's zebras (Equus Grevyi), 21 female and 3 male Böhm's zebras (Equus Burchelli Boehmi), 4 female dammar zebras ((Equus Burchelli antiquorum), and 9 female and 2 male Hartman's zebras (Equus zebra Hartmanae) were examined. The animals were derived from three sources. They were either captured in Africa and brought to the Zoological Garden at Dvůr Králové in 1972-1976, or were purchased from other zoological gardens or other sources, or were born and reared in the Zoological Garden at Dvůr Králové. All of them were more than one year old (an exact assessment of age in zebras imported from Africa or obtained by purchase is a problem).

The zebras were housed in modern stables allowing sufficient entrance of sunlight, heated in cold months and well-ventilated. Air ammonia level was measured once a week and litter was changed daily. Under favourable weather conditions the animals were regularly turned out to roam in sufficiently large open-air enclosures.

Feeding: Hay in winter, green fodder in summer, with occasional straw supplementation, on an ad libitum basis. Further supplementary feeding: $200 \mathrm{~g}$ Zoo I granulated feed, $1300 \mathrm{~g}$ oats and $30 \mathrm{~g}$ Vitasa (a commercial mineral feed mixture) per animal per day. The animals were fed twice a day, but being.kept in herds, could not be fed individually. Hygienically safe well water was available ad libitum.

At the time of blood collection all animals under study were in good bodily condition and clinically healthy. Occasionally they shed Parascaris equorum. Faecal examination during the period in which blood collections were made revealed a negligible incidence of Parascaris equorum eggs. Regular parasitological checks and an effective preventive treatment brought the incidence of these parasites under control.

Before being blood-sampled, the zebras were immobilized by subcutaneous administration of Immobilone (Reckit and Colman Pharmaceutical Division, Hull, Ireland) in doses recommended by the manufacturer. Blood collections were made about noon in various seasons as shown in Table 2.

Table 2

Months of examination of the peripheral blood in female zebras of the species kept in the Zoo at Dvưr Králové

\begin{tabular}{|l|c|c|c|c|c|c|c|c|c|c|c|c|c|}
\hline & & \multicolumn{7}{|c|}{$\begin{array}{c}\text { No. zebras blood-sampled for haematological examination of the } \\
\text { peripheral blood in individual months }\end{array}$} \\
\hline Species & N & I & II & III & IV & V & VI & VII & VIII & IX & X & XI & XII \\
\hline Grévy's zebra & 30 & - & 1 & 3 & - & 1 & 4 & 7 & 9 & 5 & - & - & - \\
Böhm's zebra & 21 & - & - & - & - & 2 & - & - & - & - & 3 & 6 & 10 \\
Dammar zebra & 4 & - & 1 & - & 1 & 2 & - & - & - & - & - & - & - \\
Hartman's zebra & 9 & - & - & - & - & 2 & - & - & - & 6 & 1 & - & - \\
\hline
\end{tabular}

$\mathbf{N}=$ Total number of animals examined. 


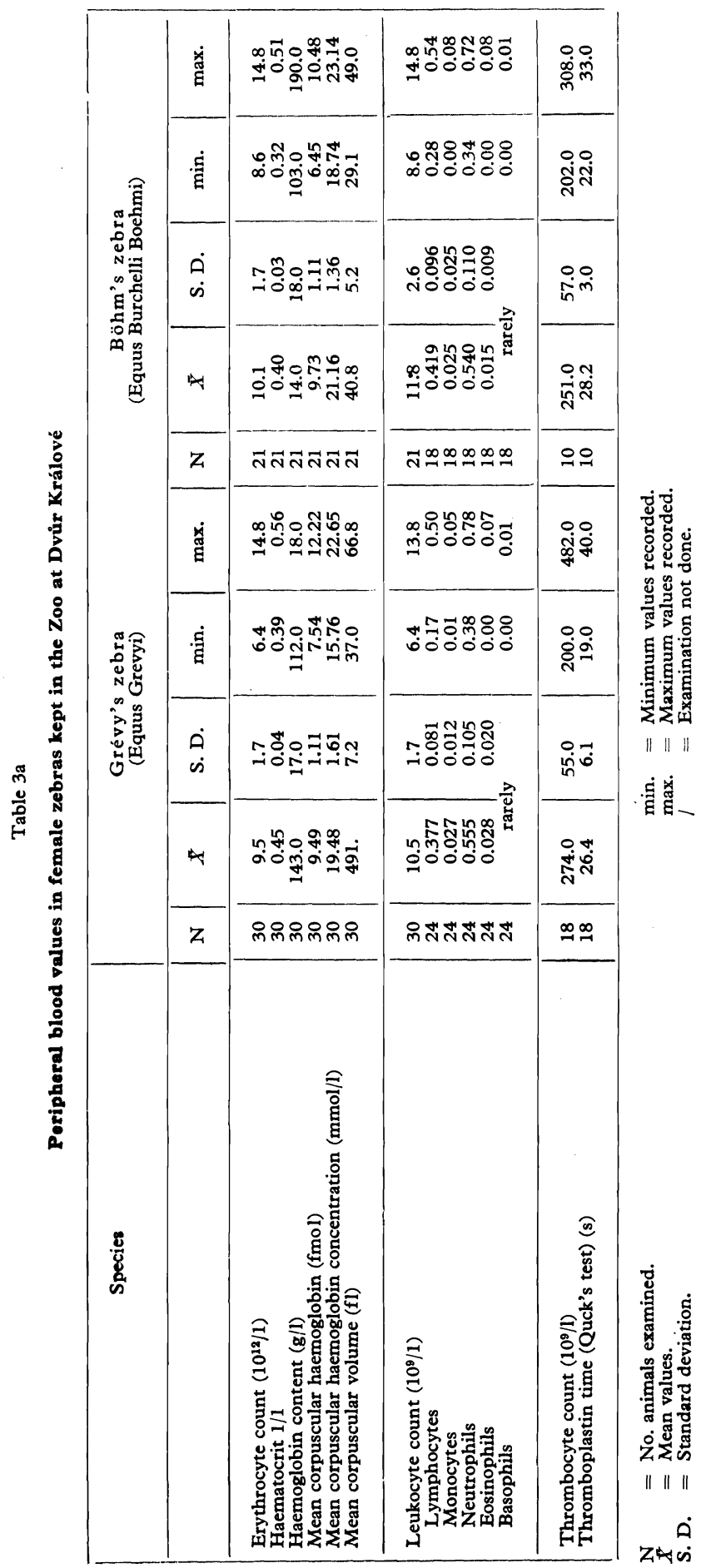




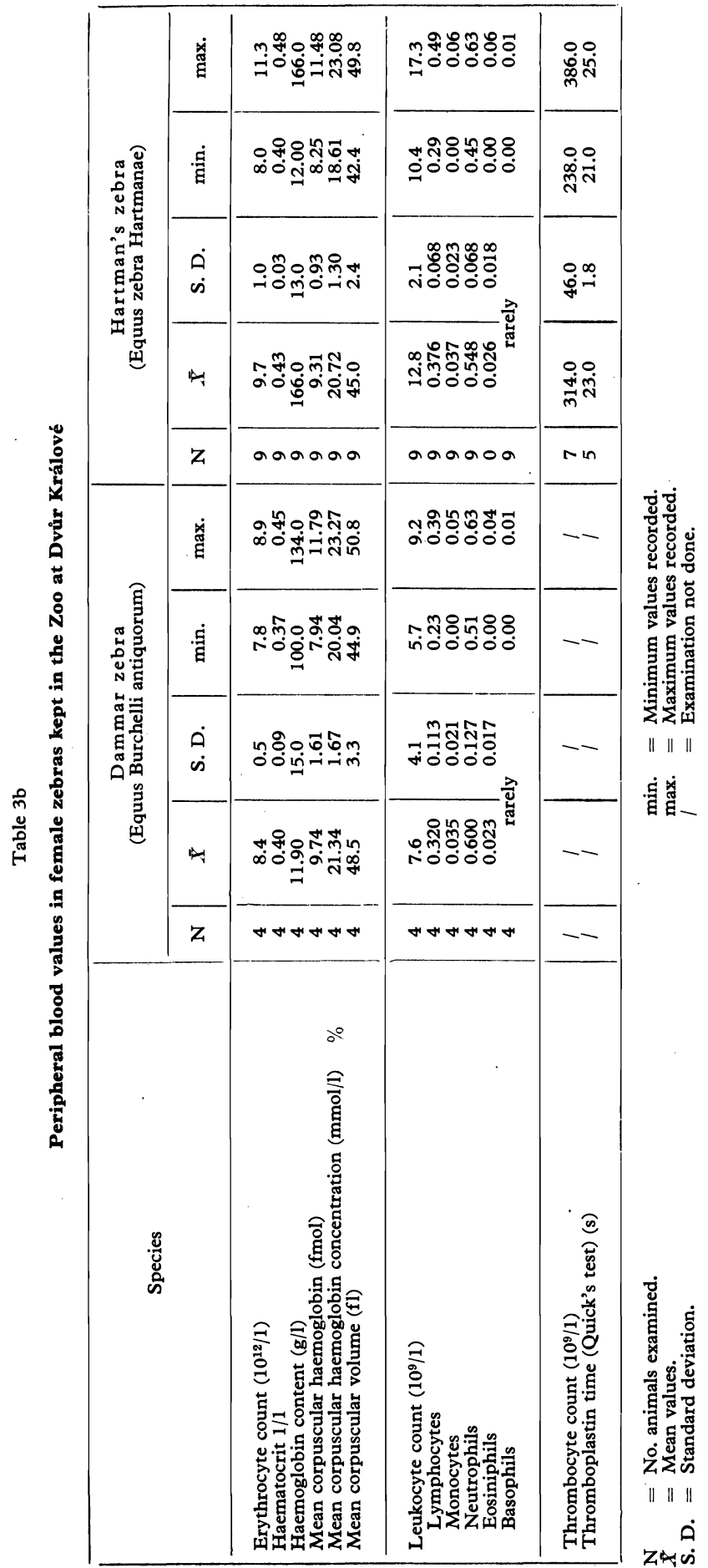


Blood samples were taken from the vena saphena medialis of the hind leg with a dry syringe. Blood was first withdrawn for the estimation of coagulation time, Quick's test and thrombocyte count. Afterwards blood was sampled into a little glass bottle containing a dried anticoagulant ( $\mathrm{K}_{2}$ EDTA). This non-coagulable venous blood was used for the estimation of erythrocyte count, haemoglobin content, haematocrit and leukocyte count, and smeared for differential leukocyte count. The haematological parameters were estimated by standard techniques used in laboratories and recommended by the Czechoslovak Society of Haematology (Jan ele et al. 1980).

From values obtained in the individual groups, mean values $(\bar{X})$ and standard deviations (S. D.) were calculated. Significance of the differences of the means was analysed using Student's t-test. Prior to applying Student's t-test the agreement of the variances was assessed by the $F$ test at the 5 per cent level of significance and a modification of the t-test was chosen accordingly.

\section{Results}

Mean haematological values for female zebras of the species tested are summarized in Tables $3 a$ and $3 b$. Statistical evaluation of the differences of the mean peripheral blood values between female zebras of the species under study is given in Table 4 .

Mean haematological values for male zebras of the species under study are given in Table 5 .

In female Grévy's zebras, a comparison was made of the mean haematological values in animals obtained from different sources (Tables 6 and 7).

\section{Discussion}

In comparing the mean peripheral blood values obtained in our study with those reported by other writers (Table 1) the criterion of reliability was the relation between the mean values reported by these writers (Tables $1 \mathrm{a}$ and $1 \mathrm{~b}$ ) and the confidence interval relating to one standard deviation as computed in the present study.

For the Grévy's zebra, Ha w key (1975) found higher values for haemoglobin content, mean corpuscular haemoglobin concentration, mean corpuscular volume, monocytes and neutrophils.

For the Böhm's zebra, Hawkey (1975) reported lower values for erythrocyte count, higher haematocrit values, a larger corpuscular volume, a smaller leukocte count, a smaller proportion of lymphocytes and fewer thrombocytes. Jones (1976) reported higher values for mean corpuscular haemoglobin and mean corpuscular volume, and fewer thrombocytes.

For the Hartman's zebra, Hawkey (1975) reported lower values for erythrocyte count, haematocrit, leukocyte count and thrombocyte count and a higher proportion of neutrophil granulocytes. Jones (1976) found lower values for haematocrit, leukocyte count, a smaller proportion of neutrophil granulocytes and fewer thrombocytes.

The causes of the aforementioned differences in some peripheral blood values are difficult to analyse. As pointed out at the beginning of the present report, they may be seen in factors related to the climatic and animal husbandry conditions under which zebras are kept. Added to this are other possible causes, particularly the state of the animal at the time of blood withdrawal. This state of the animal is affected, to a considerable degree, by pretreatment and the mode of blood withdrawal.

In non-domesticated animals three modes of blood collection are possible in principle:

a) blood collection from captured animals without previous pharmacological treatment;

b) blood collection from captured animals after pharmacological pretreatment; and

c) blood collection from pharmacologically immobilized animals. 
Table 4

Statistical significance of the differences between the peripheral blood values obtained for female zebras of the species kept in the Zoo at Dvưr Králové (assessed by Student's t-test)

Peripheral blood values compared

Zebra groups compared

Erythrocyte count

Haematocrit

Haemoglobin content

Mean corpuscular haemoglobin

Mean corpuscular haemoglobin concentration

Mean corpuscular volume

Leukocyte count
Lymphocytes
Monocytes
Neutrophils
Eosinophils
Basophils

Thrombocyte count

Thromboplastin time (Quick's test)

$A=$ Female Grévy's zebras $(\mathbf{N}=30)$.

$B=$ Female Böhm's zebras $(\mathbf{N}=21)$.

$\mathrm{C}=$ Female dammar zebras $(\mathrm{N}=4)$.

$\mathrm{D}=$ Female Hartman's zebras $(\mathrm{N}=9)$.

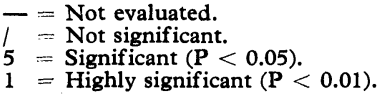

Table 5

Peripheral blood values in male zebras kept in the Zoo at Dvưr Králové (D. K.)

\begin{tabular}{|c|c|c|c|c|c|c|c|c|}
\hline Species & \multicolumn{3}{|c|}{ Grévy's zebra } & \multicolumn{3}{|c|}{ Böhm's zebra } & \multicolumn{2}{|c|}{ Hartmsn' zebra } \\
\hline Origin of the animal & capture & $\begin{array}{l}\text { Zoo } \\
\text { D. K. }\end{array}$ & $\begin{array}{l}\text { Zoo } \\
\text { D. K. }\end{array}$ & import & import & import & capture & import \\
\hline Age of the animal & - & 3 & 6 & - & - & - & - & - \\
\hline Month of examination & VII & VIII & VIII & $\mathbf{X I}$ & $\mathbf{X I}$ & XI & V & IX \\
\hline $\begin{array}{l}\text { Erythrocyte count }\left(10^{12} / \mathrm{l}\right) \\
\text { Haematocrit } 1 / 1 \\
\text { Haemoglobin content }(\mathrm{g} / \mathrm{l}) \\
\text { Mean corpuscular haemoglobin }(\mathrm{fmol}) \\
\text { Mean corpuscular haemoglobin }\end{array}$ & $\begin{array}{c}9.7 \\
0.52 \\
150.0 \\
9.55\end{array}$ & $\begin{array}{c}11.2 \\
0.48 \\
158.0 \\
8.68\end{array}$ & $\begin{array}{c}10.8 \\
0.51 \\
186.0 \\
10.61\end{array}$ & $\begin{array}{c}10.4 \\
0.44 \\
154.0 \\
9.18\end{array}$ & $\begin{array}{c}11.2 \\
0.48 \\
180.0 \\
9.93\end{array}$ & $\begin{array}{c}10.4 \\
0.44 \\
154.0 \\
9.18\end{array}$ & $\begin{array}{c}9.2 \\
1 \\
122.0 \\
8.19\end{array}$ & $\begin{array}{c}11.3 \\
0.48 \\
15 \dot{0} .0 \\
8.25\end{array}$ \\
\hline $\begin{array}{l}\text { concentration (mmol/l) } \\
\text { Mean corpuscular volume (fl) }\end{array}$ & $\begin{array}{l}17.87 \\
53.5\end{array}$ & $\begin{array}{l}20.41 \\
42.6\end{array}$ & $\begin{array}{l}22.65 \\
47.0\end{array}$ & $\begin{array}{l}21.72 \\
42.1\end{array}$ & $\begin{array}{l}23.27 \\
42.6\end{array}$ & $\begin{array}{l}21.72 \\
42.1\end{array}$ & l & $\begin{array}{l}19.42 \\
42.4\end{array}$ \\
\hline $\begin{array}{l}\text { Leukocyte count }\left(10^{9} / 1\right) \\
\text { Lymphocytes } \\
\text { Monocytes } \\
\text { Neutrophils } \\
\text { Eosionphils } \\
\text { Basophils }\end{array}$ & $\begin{array}{c}10.5 \\
0.18 \\
0.01 \\
0.78 \\
0.03 \\
0.00\end{array}$ & $\begin{array}{l}8.1 \\
0.41 \\
0.02 \\
0.55 \\
0.02 \\
0.00\end{array}$ & $\begin{array}{l}8.8 \\
0.19 \\
0.01 \\
0.69 \\
0.10 \\
0.00\end{array}$ & $\begin{array}{c}17.3 \\
1 \\
1 \\
1 \\
1\end{array}$ & $\begin{array}{c}11.9 \\
0.38 \\
0.01 \\
0.60 \\
0.01 \\
0.00\end{array}$ & $\begin{array}{c}17.3 \\
! \\
l \\
! \\
1\end{array}$ & $\begin{array}{l}13.8 \\
0.43 \\
0.03 \\
0.53 \\
0.01 \\
0.00\end{array}$ & $\begin{array}{c}13.4 \\
0.35 \\
0.09 \\
0.58 \\
0.02 \\
0.00\end{array}$ \\
\hline $\begin{array}{l}\text { Thrombocyte count }\left(10^{9} / \mathrm{l}\right) \\
\text { Blood coagulation time (Lee White) (s) } \\
\text { Thromboplastin time (Quick's test) (s) }\end{array}$ & $\begin{array}{r}284 \\
285 \\
20\end{array}$ & $\begin{array}{r}375 \\
245 \\
34\end{array}$ & $\begin{array}{r}304 \\
220 \\
\end{array}$ & $\begin{array}{l}1 \\
1 \\
1\end{array}$ & ! & $\begin{array}{l}l \\
! \\
1\end{array}$ & $\begin{array}{l}1 \\
1 \\
1\end{array}$ & $\begin{array}{r}336 \\
l\end{array}$ \\
\hline
\end{tabular}

$1=$ Examination not done. 


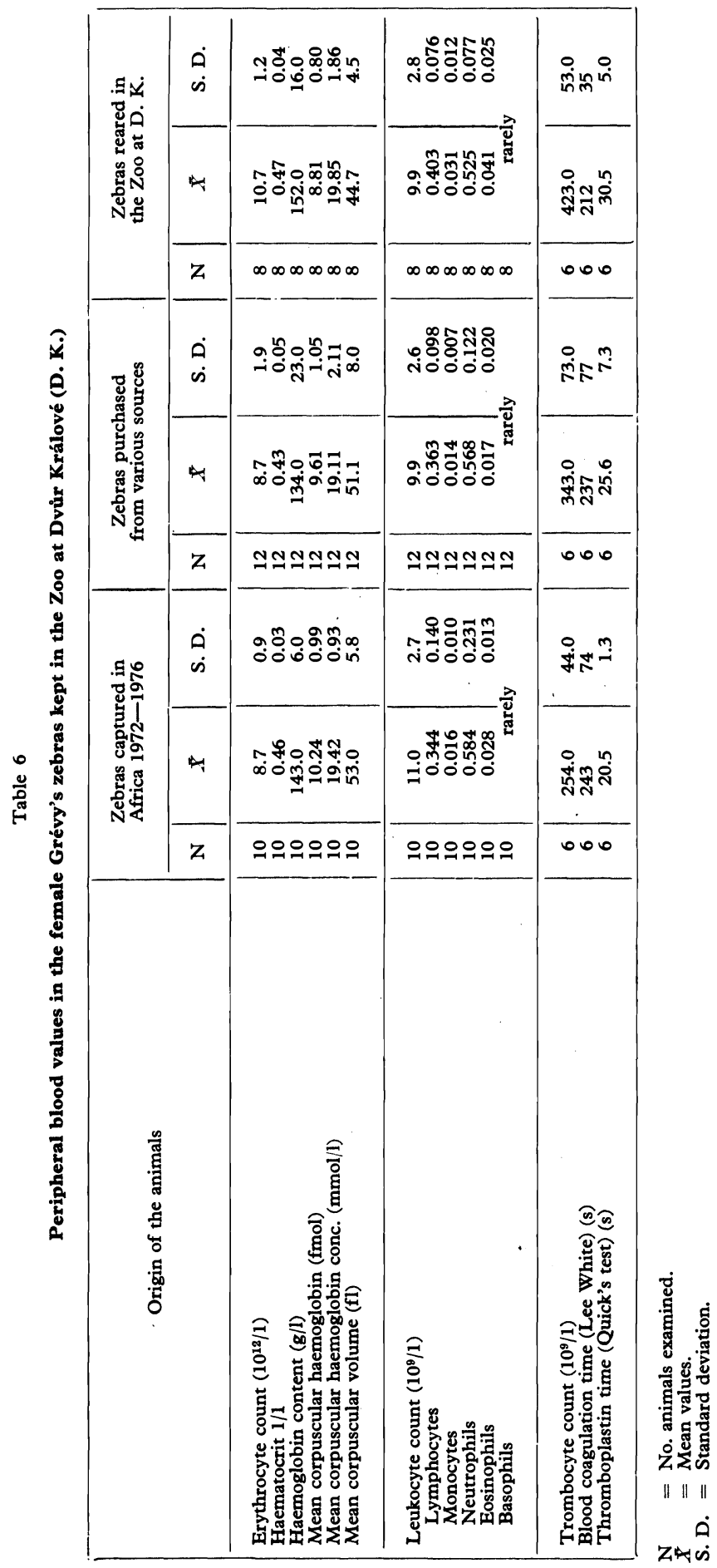


Statistical significance of the differences between the mean haematological values in the peripheral blood of the female Grévy's zebras (Equus Grevyi) kept in the Zoo at Dvưr Králové and divided into three groups according to their origin

\begin{tabular}{|c|c|c|c|}
\hline \multirow{2}{*}{ Peripheral blood value compared } & \multicolumn{3}{|c|}{ Zebra groups compared } \\
\hline & $A: B$ & $A: C$ & B : C \\
\hline $\begin{array}{l}\text { Erythrocyte count } \\
\text { Haematocrit } \\
\text { Haemoglobin content } \\
\text { Mean corpuscular haemoglobin } \\
\text { Mean corpuscular heemoglobin conc. } \\
\text { Mean corpuscular volume }\end{array}$ & $\begin{array}{l}1 \\
1 \\
1 \\
1 \\
1 \\
1\end{array}$ & $\begin{array}{l}1 \\
1 \\
1 \\
1 \\
1 \\
1\end{array}$ & $\begin{array}{l}1 \\
1 \\
1 \\
1 \\
1 \\
1\end{array}$ \\
\hline $\begin{array}{l}\text { Leukocyte count } \\
\text { Lymphocytes } \\
\text { Monocytes } \\
\text { Neutrophils } \\
\text { Eosinophils } \\
\text { Basophils }\end{array}$ & $\begin{array}{l}1 \\
1 \\
1 \\
1 \\
1 \\
-\end{array}$ & $\begin{array}{l}1 \\
1 \\
1 \\
1 \\
5 \\
-\end{array}$ & $\begin{array}{l}1 \\
1 \\
5 \\
1 \\
1 \\
-\end{array}$ \\
\hline $\begin{array}{l}\text { Thrombocyte count } \\
\text { Blood coagulation time } \\
\text { Thromboplastin time (Quick's test) }\end{array}$ & $\begin{array}{l}1 \\
1 \\
1\end{array}$ & $\begin{array}{l}1 \\
1 \\
1\end{array}$ & $\begin{array}{l}1 \\
1 \\
1\end{array}$ \\
\hline
\end{tabular}

A = Female Grévy's zebras brought from Africa in 1972-1976.

B $=$ Female Grévy's zebras purchased from various sources.

$\mathrm{C}=$ Female Grévy's zebras born in the Zoo at Dvủr Králové.

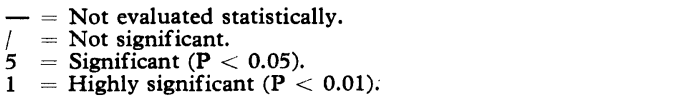

All the three modes of blood collection constitute an intervention that may markedly affect the instantaneous blood composition by neuro-humoral mechanisms or pharmacological effects of the drugs employed.

Capture of an animal without use of tranquilizing or immobilizing drugs produces stress with resultant marked shifts in haematological values of the peripheral blood as was demonstrated, for example, by Gohary and Bickhardt (1979) in sheep and by Bickhardt and Wirtz (1978) in swine. The changes found in animals of the two species included substantial increases in erythrocyte count, haemoglobin content and haematocrit values.

Effects on peripheral blood values produced by immobilization with xylazine alone and in combination with etorphine were investigated in impalas (Aepyceros melampus) by Drevemo and Karstad (1974) and in brindled gnus (Connchaetes taurinus taurinus) and cape elands (Taurotragus oryx) by Drevemo, Grootenhuis and Karstad (1974).

Therefore the handling of the animal before blood withdrawal is not only to be regarded as part of the blood coolection itself but should also be taken into consideration in evaluating the peripheral blood values. The question remains whether the mode of blood collection will affect peripheral blood values of diseased animals in the same or a similar way as in clinically healthy ones. Viewed in this light, investigations into the effects of immobilization on peripheral blood values are a prerequisite for a meaningful evaluation of these values in some animal species kept in zoos and will be the subject of our further experimental studies. 
In Materials and Methods the experimental animals were described by us as "clinically healthy". This term was used here to obviate, to a certain extent, the rather intricate problem of defining the health condition of our experimental animals more accurately. Basic clinical examination was carried out on immobilized animals. Drevemo and Karstad (1974) demonstrated the effects of immobilization on body temperature, heart rate and respiratory rate in impalas (Aepyceros melampus).

However, we are in ignorance even of these basic clinical data under physiological conditions in most animal species kept in zoos, including zebras. Further clinical examination (adspection, auscultation, palpation, etc.) is also carried out on animals in non-physiological states and its results are therefore questionable. A certain degree of insight into the situation is derived from herd history and, occasionally, case history facts emerging from regular veterinary inspections and daily observatins by animal attendants and possibly from the results of previous parasitological, microbiological and serological examination.

Koči (1979) summarized this problem as follows: "Methods of examination used in farm animals for obtaining physiological data can be applied to only a very limited extent to animals kept in zoos" and concluded by saying: "For a veterinary practitioner working in a zoo under our present conditions, i.e. without telemetry, the situation is even more difficult because capture of an animal for diagnosis produces changes in its heart rate, respiratory rate and body temperature. This makes an objective assessment of the actual state quite impossible«. And it is with this in view that the selection of zebras included in the groups under study should be considered. The possibility cannot be ruled out that an animal or animals included in the study were in a state of disease that might have produced discrete changes in some of the peripheral blood values.

In female Grévy's zebras we tried to evaluate the individual mean values of peripheral blood in relation to the animals' origin (Tables 6 and 7). Although significant differences were found in some mean values between the individual groups, the different origin of the zebras cannot be claimed with certainty as being the only dominant influence involved. Other factors may have come into play. The zebras that have been captured in Africa averaged over 8 years in age, thus being markedly older than those reared in our zoo that were, on average, only $21 / 2$ years old.

Another factor involved may have been seasonal variation, but these effects on the haematological values could not be evaluated because of the limited number of animals examined. We hope to be able to answer these and other questions after completing a long-term systematic study of haematological values in zebras kept in the Zoological Garden at Dvůr Králové, which we intend to conduct for several years as part of preventive examination of the health state of animals in this zoo.

In our view, haematological values obtained in clinically healthy zebras will be of help in diagnosing anaemia of various origin, inflammations and possibly some types of poisoning in diseased or suspect cases. Under the system of preventive examination of the health status of zebras, red blood picture values in particular can be a useful indicator of some nutritional deficiencies and possibly also of shortcomings in animal husbandry practices. Correct assessment of the values as a diagnostic aid will require further experience, particularly by way of comparison with results of clinical and comprehensive clinico-laboratory examination and in fatal cases also with patho-morphological findings.

In conclusion we wish to point out that the haematological blood values reported here for representatives of the individual zebra species were, no doubt, affected by all the conditions under which they were obtained and are regarded by us not as generally valid for the respective species but only as having a basic informative value. 


\section{Hematologické hodnoty periferní krve zeber chovaných ve východočeské zoologické zahradě Dvůr Králové nad Labem}

V rámci komplexní veterinární péče je uskutečňováno systematické vyšetřování klinicko-laboratorních hodnot periferní krve zviŕat chovaných ve Východočeské zoologické zahradě Dvůr Králové nad Labem.

$\mathrm{V}$ předloženém sdělení jsou výsledky hematologického vyšetření periferní krve u klinicky zdravých 30 klisen a 3 hřebců zeber Grévyho (Equus Grevyi), 21 klisen a 3 hřebců zeber Böhmových (Equus Burchelli Boehmi), 4 klisen zeber damarských (Equus Burchelli antiquorum), 9 klisen a 2 hřebců zeber Hartmanové (Equus Hartmanae). Z periferní krve byl určován počet červených krvinek, hematokrit, množství hemoglobinu, počet bílých krvinek, diferenciální rozpočet bílých krvinek, počet krevních destiček, srážlivost krve a tromboplastinový čas dle Quicka. Ze zjištěných hodnot byly vypočteny prủměrné hodnoty pro klisny jednotlivých vyšetřovaných druhủ zeber. V práci jsou diskutovány problémy definice "klinicky zdravé zvěře " $v$ podmínkách možností chovu zviŕat v zoologických zahradách a problémy spojené $s$ odběrem krve $u$ nedomestikovaných zvírat a vlivu manipulace se zvířetem při odběru krve na zjištěné hematologické hodnoty. Práce přináší orientační hematologické hodnoty periferní krve u čtyř druhů klinicky zdravých zeber chovanýck ve Východočeské zoologické zahradě.

\section{Гематологические величины периферийной крови зебры, разводимой в восточночешском зоопарке Двур-Кралове над Лабой}

В рамках комплексной ветеринарной заботы проводятся систематические исследования клинических и лабораторных величин периферийной крови животных, разводимых в Восточночешском зоопарке Двур-Кралове над Лабой.

В представленном сообщении приводятся результаты гематологических исследований периферийной крови у клинически здоровых 30 кобыл и 3 жеребцов зебры Греви (Equus Grevyi), 21 кобылы и 3 жеребцов зебры Бэме [Equus Burchelli Boehmi], 4 кобыл дамарской зебры (Equus Burchelli antiquorum), 9 кобыл и 2 жеребцов зебры Гартмановой (Equus Hartmanae). Из периферийной крови определяли численностг, красных кровяных телец, дифференциальный расчет белых телец, численность кровяных пластинок, свертываемость крови и тромбопластическое время по Квику. На основе установленных величин проводили расчет средних величин для кобыл отдельных исследуемых видов зебры. В работе обсуждаются проблемы определения «клинических здоровых животных» в условиях возможностей разведения животных в зоопарках и проблемы, связанные с отбором крови с целью получения установленных гематологических данных. В работе приводятся ориентировочные величины периферийной крови четырех видов клинически здоровых представителей зебры, разводимой в Восточночешском зоопарке.

\section{References}

BICKHARDT K., - WIRTZ, A.: Der Einfluss von Anbidestress und Fütterung auf Blutmesswerte des Schweines. Dtsch. tierärztl. Wschr., 85, 1978: 457-462.

DREVEMO, S. - GROOTENHUIS, J. G. - KARSTAD, L.: Blood Parameters in Wild Ruminants in Kenya. J. Wildl. Dis., 1, 1974: 327-334. 
DREVEMO, S. - KARSTAD, L.: The effect of Xylazine and Xylazine-etorphine-acepromazine combination on some clinical and haematological parameters in Impala and Eland. J. of Wildl. Dis., 10, 1974: 377-383.

GOHARY, G. S. - BICKHARDT, K.: Der Einfluss des Blutentnahmerstresses auf die Blutmesswerte des Schafes. Dtsch. tierärztl. Wschr., 86, 1979: 225-228.

HAWKEY, C. M.: Comparative mammalian haematology - Cellular Components and Blood Coagulation of Captive Wild Animals. William Heinemann Medical Books LTD., London, $1975,310 \mathrm{p}$.

JANELE, J. - CIESLAR, P. - HRODEK, O. - MALÁSKOVÁ, V. - POCH, T. - VORLOVÁ, Z.: Hematologické vyšetřovací metody Česká hematologická společnost, edited by Česká lékařská společnost, Praha, 1980.

JONES, D. M.: The Husbandry and Veterinary Care of Wild Horses in Captivity. Equine vet. J., 8, 1976: 140-146.

KOČÍ, P.: Nemoci přežvýkavcủ. In "Studijní informace» $2 / 79$, str. $39-57$. Ústav pro další vzdělávání veterinárních lékař̉u. Oddělení veterinární osvěty, Pardubice, 1979.

MASUI, M. - SAITO, M. - NARASHIMA, E.: Treatment of Overgrown Hooves in a Champan s Zebra (Equus burchelli Champani) in: Ippen R., Schöder H. D., Erkreankungen der Zootiere. Verhandlungsbericht des XVII Internationalen Symposiums über die Erkrankungen der Zootiere. TUNIS 1975, Akademie-Verlag., Berlin, 1975: 85-92.

SEAL, U. S. - SCHOBERT, E. E. - GRAY, C. W.: Baseline Laboratory Data for the Grant's Zebra. J. Zoo Animal Med., 8, 1977: 7-16. 